\title{
Corporate Board Attributes and Firm Performance of Publicly Traded Manufacturing Companies in Bangladesh
}

\author{
Md. Maniruzzaman ${ }^{1 *}$ Syed Zabid Hossain ${ }^{2}$ \\ 1.Assistant Professor, Department of Accounting and Information Systems, University of Rajshahi, \\ Rajshahi-6205, Bangladesh \\ 2.Professor, Department of Accounting and Information Systems, University of Rajshahi, Rajshahi-6205, \\ Bangladesh
}

\begin{abstract}
The study examines the effects of corporate board attributes on firm financial performance of publicly traded manufacturing companies in Bangladesh in the light of 'comply or explain' based on Corporate Governance Notifications (CGN) 2006 and 'mandatory' CGN 2012 of Bangladesh Securities and Exchange Commission (BSEC). BSEC makes the CGN mandatory in 2012 to ensure good governance at firm level. The regression results show that the revised CG guidelines are not capable of influencing firm performance measured by ROA but when performance is measured using Tobin's $Q$, the revised guidelines are somewhat effective. We did not find any prior study in corporate governance literature that focuses on the effects of revised CGN 2012 on firm performance. This study is a pioneering research and it has led to an academic debate on the effectiveness of mandatory CG guidelines on corporate attributes and hence firm performance.
\end{abstract}

Keywords: Corporate Board Attributes, Firm Performance, Corporate Governance

DOI: $10.7176 / \mathrm{RJFA} / 10-16-12$

Publication date: August $31^{\text {st }} 2019$

\section{Introduction}

The Cadbury Report in the UK (Cadbury, 1992, p. 15) defines corporate governance (CG) as "the system by which companies are directed and controlled", which includes board composition and practices and their relationship with firm performance. CG is the system of supervision and management that affects the purpose and accomplishment of the corporate objectives. It is a way to assess and control the risk of a firm to ensure its effective implementation. Good corporate governance structure encourages firms to create value through operations, research and innovation (Detthamrong et el., 2017). CG includes the concepts, theories and practices of boards and the relationship between boards and shareholders, top management, regulators and auditors and other level of stakeholders (Huq \& Bhuiyan, 2012).It is evident that good CG has a positive effect on firm's performance and market value (Chen et al., 2005; Jackling and Johl, 2009; Nguyen, 2011; Sami, Wang, \& Zhou, 2008). Thus the recent national and global corporate scams raise the necessity for evaluating performance of the board in managing firm's activities.

The monitoring abilities of a corporate board depends on its effectiveness, which in turn is determined by some factors such as board composition, board size, CEO duality, gender diversity, ownership concentration, and board culture(Brennan, 2006). Following a large number of corporate scandals around the world, considerable research on corporate governance has been done in the context of developed countries including the USA, the UK, Australia, Germany and Japan but a less attention has been given to the emerging economies like Bangladesh (Rashid, 2009; Shleifer and Visny, 1997; Gibson, 2003; Denis and McConnel, 2005). However, the country has experienced a good number of corporate collapses over the years, such as Hallmark, Bismillah group, Oriental Bank, Modern Food Ltd, Adamjee Jute Mills Ltd ( the largest jute mills in the world) along with two major stock market crashes, first one in 1996 and the second one in 2010-11(Ferdous, 2018). The researchers find mixed results as to whether board structure especially dominance of outside directors, CEO duality or even board size have an impact on firm performance (Rashid at el, 2010a; Hasan at el, 2013).

In early 2006, the Bangladesh Securities and Exchange Commission (BSEC) a regulatory body issues and promulgates the Corporate Governance Notification (CGN) on comply or explain basis. It is also known as Corporate Governance Code of Best Practices which acts as a guideline for the firms in Bangladesh to adopt good governance practices. The CGN 2006 requires listed firms to appoint independent directors in the ratio of 1:10 in line with the Anglo-American-style and then it has been revised again in 2012 as a mandatory provision where the CGN requires listed firms to appoint independent directors in the ratio of 1:5. It is worth mentioning that the CG mechanism works well in the Anglo-American countries as the jurisdiction of those countries heavily depends on the transparency of enforcement of laws to protect shareholder's rights (Asian Development Bank, 2000) which, in contrast, are found less effective in the case of emerging economies like Bangladesh as key institutional forces have little capacity to exert pressures on firms to ensure compliance (Rashid 2011). Thus the current study has been undertaken to examine the influence of corporate board attributes on firm performance in the context of Bangladesh, a rapidly growing economy. We do not find any comprehensive study in the literature that examines 
the influence of corporate board attributes on the firm performance of publicly traded manufacturing companies in Bangladesh.

This study provides an additional insight into the influence of corporate board attributes on firm performance. It is hoped that the study will provide important quantitative information into CG and add to the existing body of empirical literature, especially in a developing country context. The outcome of the study will be useful to the policy makers of manufacturing companies as this sector has not been thoroughly investigated in this regard. The remainder of this paper is organized as follows. Section 2 presents the review of literature on corporate board attributes and firm's performance such as board size, board independence, ownership concentration, CEO duality. Section 3 presents the methodological discussion. Section 4 presents the results and discussion. Section 5 presents conclusion and policy implications of the study.

\section{Literature Review}

\subsection{Board Size and Corporate Financial Performance}

The size of the corporate board plays an important role in the directors' ability to oversee and control managers (Anderson et al., 2004). A large board is more likely to provide better access to various resources than a small one. A board of directors with diverse experience and knowledge would probably have more careful learning and decision-making processes, thus resulting in better firm performance. The empirical findings on the relationship between board size and firm performance are however mixed. For example, Yermack (1996) finds a negative relationship between board size and firm performance in a sample of 452 large U.S. industrial corporations over the period 1984 and 1991. Coles et al. (2008) found that firm performance increases with board size for complex firms. However, Jackling and Johl (2009) found that board size is a positively associated with firm performance in India. Eisenberg et al. (1998) reported a negative relationship between board size and firm performance in a sample of firms in Finland. Likewise, Mak and Kusnadi (2005) found a negative relationship between board size and firm value, measured as Tobin's Q, for a sample of firms in Malaysia and Singapore. Overall, these findings suggest that as board size increases, firm performance tends to deteriorate. One plausible explanation is that large boards result in less communication between board members, poorer decisions, and ineffective coordination. In addition, firms with large boards are more likely to be controlled by the CEO. If the firms can overcome these challenges associated with the larger board, firm performance may improve. In summary, we expect the effect of board size on firm performance to be positive; therefore, we hypothesize that:

H1. Board size is positively associated with firm performance.

\subsection{Board independence and firm performance}

An independent director (also known as an outside director) plays an important role in monitoring the firm's management team. Therefore, the extent to which the board of directors is independent may attract investors (Muniandy and Hillier, 2015). Previous studies show that examine board independence and firm performance provide mixed results. On the one hand, Agrawal and Knoeber (1996) find that board independence has a negative effect on firm value, measured as Tobin's Q, in the US. On the other hand, Jackling and Johl (2009) find that board independence has a positive impact on firm performance for firms in India. Likewise, Muniandy and Hillier (2015) reported that board independence has a positive influence on firm performance in South Africa. In the context of Malaysia, Haniffa and Hudaib (2006) find that board independence does not affect firm performance. Consistent with the literature, we argue that the presence of competent independent directors in the board would improve firm performance. Therefore, we hypothesize that:

$\mathrm{H} 2$ : Board independence is positively associated with firm performance.

\subsection{Ownership Concentration and Firm Performance}

Hossain and Rahman, (2013) mention that firms in Bangladesh are mostly concentrated ownership or controlled by dominant shareholders like corporate group or government. It is apparent that management of firms is just nothing but the extension of dominant owners as a result of which CEO, executive directors and chairman are from the controlling family in most of the Bangladeshi firms. It is evident (Farooque et al. 2008) that on an average, the top five shareholders hold more than $50 \%$ of a firm's outstanding share. Imam and Malik (2007) mention that the ownership patterns of 219 companies from 12 sectors listed on Dhaka Stock Exchange are found on average $32.33 \%$ of the shares held by the top three shareholders. This percentage becomes larger in real estate, fuel and power, engineering, textile and pharmaceutical sectors. Another study discloses that firms in Bangladesh are not willing to come to the stock market for their required funds as they fear to lose control over the firms (Haque et al. 2006). Hossain and Rahman, (2013) mention that the average shareholdings of top five and top ten shareholders are 50 percent and 60 percent respectively while the largest or top 1 shareholder owns around a quarter of the firm's equity where manufacturing sector is relatively higher than the banks and insurance companies. Concentration of ownership to a small group will have a positive influence on firm's value in Bangladesh as they have more dominance over management and also incentive to monitor the affairs of management, and hence reduce 
agency conflicts (Hossain and Rahman, 2013). The bi-directional relationship between ownership concentration and firm value supports the indispensability of the role of the founder family or the Top-1 shareholder in Bangladesh. In this context, for the dominant presence of large shareholder, quasi external mechanisms (such as institutional investors, audit quality, debt ratio), are suppose to have their proper role in influencing firm value, phenomena that draw the attention of policy makers. In addition, firms in Bangladesh fail to ensure standard corporate governance practices in line with the developed countries. Thus we propose the following hypothesis: H3: There is a positive relationship between ownership concentration and firm performance.

\subsection{CEO-Chairman Duality and Firm's Performance}

Chief Executive Officer (CEO) duality refers to the leadership nature of board structure in which the CEO plays the dual role of chairman of the board also. The CEO-chairman duality enhances the possibility of violating the accounting principles and hence, the present $\mathrm{CG}$ practices in Bangladesh are highly criticized by corporate stakeholders and the unbiased segments of society, and are not acceptable to many developing countries (Hasan et al, 2014). There are two basic schools of scholars who debate on the issue of CEO duality and its impact on firm performance. On the basis of the core concept of agency theory, one school of scholars supports that separation of the CEO-Chairman positions would maximize firm performance (Gillan, 2006; Harris \& Helfat, 1998; Shleifer \& Vishny, 1997), as the board has a neutral authority to supervise the CEO's tasks. However, the empirical evidence for this relationship is inconclusive and mixed.

Another school of scholars support for same position of CEO- Chairman as it reflects the stewardship theory of management. When the two positions CEO-Chairman are performed by one person, it ensures the monitoring and implementing control throughout the firm (Adams, Almeida, \& Ferreira, 2005; Davis, Schoorman, \& Donaldson, 1997; Finkelstein \& D'Aveni, 1994). Previous studies thus indicate both dual CEO and non-dual CEO firm can increase firm performance which is inconclusive to generate a single direction (Brickley, Coles, \& Jarrell, 1997; Cannella \& Lubatkin, 1993; Daily \& Dalton, 1997; Donaldson \& Davis, 1991). We hypothesize that H4: There is a negative relationship between CEO duality and corporate performance.

\section{Methodology}

\subsection{Population and sampling}

This study is empirical in nature. Data have been collected from the published annual reports of the selected companies. The annual reports have been collected from the websites of the selected companies and DSE library. A total of 85 companies have been selected for the study while the total manufacturing companies is 150 . Initially, the sample has been taken from firms listed on or before 2006 on the DSE. After eliminating the companies with missing data, the sample size has been 85 listed firms. We have taken this sample for data collection throughout the twelve years period. The sample size is representative because market capitalization of 85 selected companies is approximately $69.02 \%$ of the total market capitalization of the listed manufacturing companies in Bangladesh as on December 31, 2017. Chauhan et al. (2016) conducted a study in India for the period 2003-2013, where they include all manufacturing firms in India and initially find a total 970 firms but reports are available for 84 firms representing market capitalization of $55.49 \%$. Rashid (2016) conducted a study in Bangladesh for the period of 2001-2011 with the sample of all non-financial companies listed on the DSE but based on the availability of annual reports, his sample includes only 110 companies, resulting in a balanced sample of 1210 observations.

The years 2006-2017 have been selected as the BSEC, the chief market regulator of Bangladesh capital market, issues Corporate Governance Notifications (CGN) in 2006 on comply or explain basis and then issued revised CGN in 2012 on mandatory basis. Thus the current study examines whether the revised CGN in 2012 aids for the betterment of corporate board attributes in Bangladesh.

\subsection{Measurement of dependent and independent variables}

In the corporate governance literature, there are two types of measurement of firm performance: accounting measures (Elsayed 2007; Masulis et al. 2012) and market value measures (Elsayed, 2007; Black and Kim, 2012). However, the capital market in Bangladesh is underdeveloped and highly volatile in nature, and thus market based measures are not greatly responsive to firm's economic performance. So, accounting based measures have been used in this study. Hence, the current study has used ROA (return on assets) as a measure of firm performance because it reflects the results of underlying firm's economic performance. However, to check the robustness of the results, the study also uses Tobin's Q as alternative performance measure of firm performance. The independent variables of the study are board size, board independence, ownership concentration, and CEO duality. Board size refers to the number of board members in the corporate board. Board independence refers to the ratio of independent directors to the total number of board members in the board. Ownership concentration refers to the proportion of shareholdings by the sponsor directors of the company as per the DSE shareholding pattern. CEO duality is a dummy variable which takes a value of zero if the same person holds the position of CEO and Chairman of the board and 1 otherwise. 


\subsection{Statistical model}

To examine the influence of corporate board attributes on firm performance, the following regression model has been developed:

Yit $=\beta 0+\beta 1 \times$ BDSIZEit $+\beta 2 \times$ BDINDit $+\beta 3 \times$ OWNCONit $+\beta 4 \times$ CEODUALit $+\beta$ j Controlit $+\varepsilon$ it

Where,

Yit is alternatively ROAit, Tobin's Qit

BDSIZEit is the board size for ith firm at time $t$.

BDINDit is the board independence for ith firm at time $t$.

OWNCONit is the ownership concentration for ith firm at time $t$.

CEODUALit is the CEO duality for ith firm at time $t$.

Controlit is the control variables used in the study

$\beta 0$ is the intercept, $\beta 1, \beta 2, \beta 3$, and $\beta 4$ are the regression co-efficient

cit is the error terms

\section{Results and Discussion}

The descriptive statistics indicates that the average firm performance of the companies measured as ROA is 8.91 percent ranging from (-26) percent to 56 percent while the average firm performance measured as Tobin's Q is 106.73 percent ranging from 51 percent to 152 percent over a period of 2006-2017, which indicates that for every BDT 100 invested in asset there is a return of BDT 6.73. The average board size of the sample companies is 7.1556 ranging from 2 to 14 . The average board independence of the sample companies is 1.3943, which indicates that on average more than one outside directors sits on the corporate board as independent directors. The average equity share owned by the sponsor directors of manufacturing companies is 44.7615 percent ranging from .12 percent to 92.91 percent. The descriptive statistics also shows that on average 24.36 percent firms has the CEO duality, which indicates that on average 75.64 percent of the firms have a separate person holding the position of the CEO and chairman of the company.

Table 1 Descriptive statistics

\begin{tabular}{lrrrrrr}
\hline & \multicolumn{1}{c}{ ROA } & \multicolumn{1}{c}{ Tobin's Q } & \multicolumn{1}{c}{ BDSIZE } & \multicolumn{1}{c}{ BDIND } & OWNCON & CEODUAL \\
\hline Mean & .0891 & 1.0673 & 7.1556 & 1.3943 & 44.7615 & .7564 \\
Median & .0751 & 1.0552 & 7.0000 & 1.0000 & 47.6000 & 1.0000 \\
Std. Deviation & .09347 & .11570 & 1.86434 & .66433 & 17.69749 & .42945 \\
Minimum & -.26 & .51 & 2.00 & 1.00 & .12 & .00 \\
Maximum & .56 & 1.52 & 14.00 & 5.00 & 92.91 & 1.00 \\
\hline
\end{tabular}

To check the multicollinearity problem, we conducted Person correlation analysis on the variables. The results show that ROA and Tobin's Q are positively correlated. Besides, board size, board independence, and ownership concentration are also positively correlated with ROA and Tobin's Q but CEO duality is negatively correlated with ROA which in turn positively correlated with Tobin's Q. The correlation matrix also shows that no variable is correlated with more than 50 percent, and hence there is no multicollinearity problem. Thus the variables are eligible for regression analysis.

Table 2. Correlations coefficient matrix

\begin{tabular}{|c|c|c|c|c|c|c|}
\hline Variables & $\mathrm{ROA}$ & Tobin's Q & BDSIZE & BDIND & OWNCON & CEODUAL \\
\hline ROA & 1 & & & & & \\
\hline Tobin's Q & $.231^{* *}$ & 1 & & & & \\
\hline BDSIZE & $.146^{* *}$ & $.078^{*}$ & 1 & & & \\
\hline BDIND & $.076^{*}$ & .033 & $.307^{* *}$ & 1 & & \\
\hline OWNCON & $.269^{* *}$ & $.154^{* *}$ & $.174^{* *}$ & .051 & 1 & \\
\hline CEODUAL & -.009 & $.120^{* *}$ & .048 & .016 & $.067^{*}$ & 1 \\
\hline
\end{tabular}

Table 3 presents the regression results, which are quite revealing. It is evident that board size, board independence and ownership concentration are positively and CEO duality is negatively associated with ROA, but only the ownership concentration is statistically significant. Similarly, board size and ownership concentration are positively associated with Tobin's Q and the association is significant. Ownership concentration is a common feature in South-Asian countries and our study support the need for concentration of corporate ownership in the hands of a few individuals and institutional investors to produce better incentives for equityholders to exercise rigorous monitoring process so as to enhance operational efficiency and minimize agency cost, and thus lead to superior performance. Concomitantly, the significant adverse effect of CEO duality on firm performance as measured by ROA and very insignificant positive effect as measured by Tobin's Q suggest the need for firms to separate the post of CEO and chairman to ensure good governance and hence good performance. Contrarily, board independence is negatively associated with Tobin's Q and the same is statistically insignificant. Independent Directors are appointed on the board to look after the interest of the let alone minority shareholders and ensure that 
any deceitful or inept action of corporate management does not go unnoticed. In ideal world, an independent director should have independence of mind along with ability and ethical foundation to judge an issue without prejudice or bias towards the interest of any individual or group of individuals. But in the context of developing countries especially in Bangladesh, the reality is somewhat different. In most of the cases, independent directors usually try to protect the interest of dominant/ majority shareholders instead of minority shareholders and all other stakeholders. The revealing feature is that the appointment of independent directors is normally controlled by controlling shareholders. Moreover, it is difficult to find any truly independent person for appointing as independent director in corporate boards. In such a situation, BSEC could prepare a panel of deserving candidates having sound ethical and professional background and make it mandatory to appoint independent directors from that panel following chronological order. Consequently, board independence and firm performance will increase. There will be a win-win situation both for the minority and majority shareholders and good governance will prevail in the corporate sector in Bangladesh.

On the other hand, control variables such as firm size and firm age are positively associated with ROA and the results are statistically significant. One possible explanation is that the older firm and the larger the size, the higher the firm performance (Dey et al., 2018) However, firm size is negatively and firm age is positively associated with Tobin's Q and in both the cases the results are statistically significant. Another revealing feature is that all the sectors under manufacturing category are negatively associated with ROA' and the results are statistically significant. Similarly, all sectors are negatively associated with Tobin's Q except cement sector and the results are statistically significant in case of Ceramics, Paper, Engineering, Jute and Textile sectors but in case of Cement, Pharmaceuticals and Tannery sectors, the regression results are not statistically significant. SECCODE is negatively associated with ROA and the association is statistically significant, but SECCODE is positively associated with Tobin's Q and the result is not statistically significant.

Table 3. Regression results

\begin{tabular}{|c|c|c|c|c|c|c|c|c|}
\hline \multirow[t]{2}{*}{ Variables } & \multicolumn{3}{|c|}{ ROA } & \multicolumn{3}{|c|}{ Tobin's Q } & \multicolumn{2}{|c|}{ Collinearity Statistics } \\
\hline & Beta & $\mathbf{T}$ & Sig. & Beta & $\mathbf{T}$ & Sig. & Tolerance & VIF \\
\hline (Constant) & & -3.681 & .000 & & 31.682 & .000 & & \\
\hline BDSIZE & .017 & .460 & .646 & .163 & 4.111 & .000 & .660 & 1.514 \\
\hline BDIND & .050 & 1.369 & .172 & -.036 & -.921 & .358 & 679 & 1.473 \\
\hline OWNCON & .248 & 7.727 & .000 & .149 & 4.329 & .000 & .878 & 1.138 \\
\hline CEODUAL & -.013 & -.331 & .741 & .091 & 2.239 & .025 & .632 & 1.582 \\
\hline LNFSIZE & .284 & 8.141 & .000 & -.445 & -11.915 & .000 & .742 & 1.348 \\
\hline FAGE & .173 & 4.923 & .000 & .199 & 5.306 & .000 & .738 & 1.355 \\
\hline SECCODE & -.206 & -5.715 & .000 & .049 & 1.261 & .208 & .697 & 1.435 \\
\hline Cement & -.285 & -6.635 & .000 & .007 & .161 & .872 & .490 & 2.042 \\
\hline Ceramics & -.252 & -6.993 & .000 & -.110 & -2.841 & .005 & .697 & 1.436 \\
\hline Paper & -.133 & -4.134 & .000 & -.076 & -2.212 & .027 & .874 & 1.144 \\
\hline Engineering & -.329 & -6.748 & .000 & -.103 & -1.979 & .048 & .381 & 2.626 \\
\hline Jute & -.235 & -6.752 & .000 & -.131 & -3.537 & .000 & .751 & 1.332 \\
\hline Textile & -.539 & -9.946 & .000 & -.207 & -3.577 & .000 & .308 & 3.243 \\
\hline Pharmaceuticals & -.292 & -5.417 & .000 & -.020 & -.345 & .730 & .312 & 3.206 \\
\hline Tannery & -.191 & -4.824 & .000 & -.033 & -.777 & .437 & .576 & 1.736 \\
\hline \multicolumn{4}{|c|}{ Dependent variable: $R O A$} & \multicolumn{5}{|c|}{ Dependent Variable: Tobin's $Q$} \\
\hline \multicolumn{4}{|c|}{ F statistics } & \multicolumn{5}{|c|}{17.570} \\
\hline \multicolumn{2}{|l|}{ Significance } & \multicolumn{2}{|c|}{$.000^{\mathrm{b}}$} & \multicolumn{5}{|c|}{$.000^{\mathrm{b}}$} \\
\hline R Square & & \multicolumn{2}{|c|}{.364} & & & .273 & & \\
\hline
\end{tabular}

*Food and Allied sector is a reference category, which takes a value zero. The manufacturing companies in Bangladesh are categorized into

Nine different sectors as per the Dhaka Stock Exchange, which are Cement, Ceramics, Paper, Engineering, Jute, Textile, Pharmaceuticals, Tannery and Food and Allied.

*SECCODE is a dummy variable, where BSEC's guidelines, 2006 takes value zero and BSEC's guidelines, 2012 takes value 1 (one)

Thus, on the whole, it can be concluded that the revised mandatory CG Guidelines fails to add any value to corporate board attributes and hence performance of publicly traded manufacturing companies in Bangladesh.

\section{Conclusion}

The current study has strived to examine the effects of corporate board attributes on firm financial performance of publicly traded manufacturing companies in Bangladesh taking the effects of BSEC's guidelines on corporate governance to see whether the revised CGN in 2012 adds any value to the corporate board attributes which in turn influence firm performance. We know BSEC issues CGN in 2006 on comply or explain basis and then make it 
mandatory in 2012 to ensure good governance at firm level management. The empirical results show that the revised CG guidelines of 2012 have failed to add any value to corporate board attributes and thus firm performance as measured by ROA. However, firm performance as measured by Tobin's Q is somewhat better in relation to board size and $\mathrm{CO}$ duality and to some extend negative in relation to $\mathrm{CO}$ duality. We know these two indicators express different meanings. ROA demonstrates operational performance, while Tobin's Q expresses future prospect i.e., growth opportunities of the corporate entity and as such it is not surprising to find somewhat different results using these two measures at the same time.

We have not found any previous study in corporate governance literature that focuses on the effects of corporate board attributes on firm performance in light of the revised CG guidelines. Hence we have conducted this study and the empirical results lead us to an academic debate on the effectiveness of mandatory CG guidelines of 2012. However, the study is conducted on publicly traded manufacturing companies using secondary data only and it is quantitative in nature. Future researchers will address this debate in a detailed way taking both financial and non financial companies and using mixed method of research.

\section{References}

Adams, R.B., Almeida, H. and Ferreira, D., 2005. Powerful CEOs and their impact on corporate performance. The Review of Financial Studies, 18(4), pp.1403-1432.

Agrawal, A. and Knoeber, C.R., 1996. Firm performance and mechanisms to control agency problems between managers and shareholders. Journal of financial and quantitative analysis, 31(3), pp.377-397.

Anderson, R.C., Mansi, S.A. and Reeb, D.M., 2004. Board characteristics, accounting report integrity, and the cost of debt. Journal of accounting and economics, 37(3), pp.315-342.

Brennan, N., 2006. Boards of directors and firm performance: is there an expectations gap?. Corporate Governance: An International Review, 14(6), pp.577-593.

Code, C., 1992. The Financial Aspects of Corporate Governance. London: The Committee on the Financial Aspects of Corporate Governance and Gee and Co. Ltd.

Cannella Jr, A.A. and Lubatkin, M., 1993. Succession as a sociopolitical process: Internal impediments to outsider selection. Academy of Management Journal, 36(4), pp.763-793.

Chen, Z., Cheung, Y.L., Stouraitis, A. and Wong, A.W., 2005. Ownership concentration, firm performance, and dividend policy in Hong Kong. Pacific-Basin Finance Journal, 13(4), pp.431-449.

Coles, J.L., Daniel, N.D. and Naveen, L., 2008. Boards: Does one size fit all?. Journal of financial economics, 87(2), pp.329-356.

Daily, C.M. and Dalton, D.R., 1997. CEO and board chair roles held jointly or separately: much ado about nothing?. Academy of Management Perspectives, 11(3), pp.11-20.

Davis, J.H., Schoorman, F.D. and Donaldson, L., 1997. Toward a stewardship theory of management. Academy of Management review, 22(1), pp.20-47.

Dey, R., Hossain, S. and Rezaee, Z., 2018. Financial risk disclosure and financial attributes among publicly traded manufacturing companies: Evidence from Bangladesh. Journal of Risk and Financial Management, 11(3), p.50.

Donaldson, L. and Davis, J.H., 1991. Stewardship theory or agency theory: CEO governance and shareholder returns. Australian Journal of management, 16(1), pp.49-64.

Eisenberg, T., Sundgren, S. and Wells, M.T., 1998. Larger board size and decreasing firm value in small firms. Journal of financial economics, 48(1), pp.35-54.

Finkelstein, S. and D'aveni, R.A., 1994. CEO duality as a double-edged sword: How boards of directors balance entrenchment avoidance and unity of command. Academy of Management journal, 37(5), pp.1079-1108.

Gillan, S.L., 2006. Recent developments in corporate governance: An overview.

Haniffa, R. and Hudaib, M., 2006. Corporate governance structure and performance of Malaysian listed companies. Journal of Business Finance \& Accounting, 33(7 - 8), pp.1034-1062.

Harris, D. and Helfat, C.E., 1998. CEO duality, succession, capabilities and agency theory: Commentary and research agenda. Strategic Management Journal, 19(9), pp.901-904.

Hasan, M.S., Hossain, S.Z. and Swieringa, R.J., 2013. Corporate governance and financial disclosures: Bangladesh perspective. Corporate Governance, 4(1), pp.109-119.

Hasan, M.S., Hossain, S.Z. and Rahman, R.A., 2014. Corporate Governance and corporate accruals: The situation in Bangladesh. Aestimatio, (9), p.90.

Huq, B.I. and Bhuiyan, M.Z., 2012. Corporate governance-It's problems \& prospects in banking industry in Bangladesh. World Review of Business Research, 2(2), pp.16-31.

Jackling, B. and Johl, S., 2009. Board structure and firm performance: Evidence from India's top companies. Corporate Governance: An International Review, 17(4), pp.492-509.

Lawrence, S., Pennock, D.M., Flake, G.W., Krovetz, R., Coetzee, F.M., Glover, E., Nielsen, F.A., Kruger, A. and Giles, C.L., 2001. Persistence of web references in scientific research. Computer, 34(2), pp.26-31. 
Mak, Y.T. and Kusnadi, Y., 2005. Size really matters: Further evidence on the negative relationship between board size and firm value. Pacific-Basin finance journal, 13(3), pp.301-318.

Muniandy, B. and Hillier, J., 2015. Board independence, investment opportunity set and performance of South African firms. Pacific-Basin Finance Journal, 35, pp.108-124.

Nguyen, P., 2011. Corporate governance and risk-taking: Evidence from Japanese firms. Pacific-Basin Finance Journal, 19(3), pp.278-297.

Rashid, A., 2009, July. Board composition, board leadership structure and firm performance: Evidence from Bangladesh. In Proceedings of the 2009 AFAANZ Conference. Accounting \& Finance Association of Australia and New Zealand.

Rashid, A., De Zoysa, A., Lodh, S. and Rudkin, K., 2010. Board composition and firm performance: Evidence from Bangladesh. Australasian Accounting, Business and Finance Journal, 4(1), pp.76-95.

Sami, H., Wang, J. and Zhou, H., 2011. Corporate governance and operating performance of Chinese listed firms. Journal of International Accounting, Auditing and Taxation, 20(2), pp.106-114.

Shleifer, A. and Vishny, R.W., 1997. A survey of corporate governance. The journal of finance, 52(2), pp.737783.

Van der Geer, J., Hanraads, J.A.J. and Lupton, R.A., 2000. The art of writing a scientific article. J. Sci. Commun, 163(2), pp.51-59.

Yermack, D., 1996. Higher market valuation of companies with a small board of directors. Journal of financial economics, 40(2), pp.185-211. 